\title{
The Canadian National Dairy Study 2015-Adoption of milking practices in Canadian dairy herds
}

\author{
E. Belage,${ }^{*} \dagger$ S. Dufour, $† \ddagger$ C. Bauman, ${ }^{*}$ A. Jones-Bitton, ${ }^{*}$ and D. F. Kelton ${ }^{*} \dagger^{1}$ \\ *Department of Population Medicine, University of Guelph, Guelph, Ontario, Canada, N1G 2W1 \\ †Canadian Bovine Mastitis and Milk Quality Research Network, C.P. 5000, St-Hyacinthe, Québec, Canada, J2S 7C6 \\ łDepartment of Pathology and Microbiology, Faculty of Veterinary Medicine, University of Montreal, C.P. 5000, St-Hyacinthe, Québec, \\ Canada, J2S 7C6
}

\section{ABSTRACT}

Several studies have investigated which management practices have the greatest effect on udder health, but little information is available on how broadly the recommended milking practices are adopted across Canada. The National Dairy Study 2015 was designed to gather dairy cattle health and management data on dairy farms across Canada. The objectives of the present study were to describe the current proportions of adoption of milking practices on Canadian dairy farms, and identify factors associated with their use on farms. A bilingual questionnaire measuring use of various practices, including an udder health-specific section, was developed and sent to all Canadian dairy farms. The questions in the udder health section of the questionnaire were adapted from a bilingual questionnaire previously validated and containing questions regarding general milking hygiene and routine, and on-farm mastitis management. Chi-squared tests were used to investigate simple associations between adoption of practices and various explanatory variables including region, milking system, herd size, and bulk tank somatic cell count. In total, 1,373 dairy producers completed the survey. The regional distribution of the participants was representative of the Canadian dairy farm population, and milk quality was, on average, similar to nonparticipants. Overall, Canadian dairy producers followed the recommendations for milking procedures, but some were more extensively used than others. Forestripping, cleaning teats, wiping teats dry, using singlecow towels, and use of postmilking teat disinfectant were widely adopted. Use of gloves and glove hygiene, use of a premilking teat disinfectant, and use of automatic takeoffs were not as extensively implemented. Adoption percentages for several practices, including use of gloves, use of a premilking teat disinfectant, teat drying methods, and use of automatic takeoffs were

Received October 28, 2016.

Accepted January 24, 2017.

${ }^{1}$ Corresponding author: dkelton@uoguelph.ca significantly associated with milking system, herd size, and region. It would be helpful to explore the reasons why producers choose to adopt or ignore recommended milking practices as most are easy to include in the routine and are fairly inexpensive.

Key words: dairy cattle, udder health, milking practices, adoption

\section{INTRODUCTION}

The Canadian dairy industry is one of the largest agricultural sectors in the country and contributes over $\$ 6$ billion to the Canadian economy (Canadian Dairy Commission, 2016). Dairy farms can be found in all of Canada's 10 provinces, with the largest proportion of herds located in Ontario (33\%) and Québec (50\%) (Canadian Dairy Information Center, 2015). Mastitis is one of the most important issues that dairy producers deal with on a daily basis. Regional studies previously conducted in Canada reported low to moderate prevalences of mastitis in herds in Ontario (20 to 22\%; Sargeant et al., 1998; McLaren et al., 2006) and British Columbia (5.6 to 10.5\%; van Dorp et al., 1999). A more recent study by Olde Riekerink et al. (2008) found the mean incidence rate of clinical mastitis (IRCM) across the 10 Canadian provinces was higher than the previous reports (23.0 cases per 100 cow-years, ranging from 0.7 to 97.4 per herd; Olde Riekerink et al., 2008). Results of this latter study indicated regional differences in the IRCM and differences in prevalence of mastitis pathogens, especially among herds in western Canada, where the mean IRCM was lowest (7.6 to 20.2 cases per 100 cow-years) and environmental pathogens were more prevalent, and herds in Ontario and Québec, where mean IRCM was the highest (31.6 and 29.7 cases per 100 cow-years) and contagious pathogens were more prevalent (Olde Riekerink et al., 2008). The differences found in that study suggest an effect of different management styles, possibly also related to barn type and region, on the IRCM in herds.

Researchers have also examined which herd management practices, including overall management, housing, 
and milking, have the largest effect on udder health (Barkema et al., 1998; Chassagne et al., 2005; Dufour et al., 2011, 2012). However, little information is available on how broadly the recommended milking practices are adopted across Canada. Whereas the United States has the National Animal Health Monitoring System, an initiative of the USDA to "collect, analyze, and disseminate data on animal health, management, and productivity across the United States" (USDA-APHIS, 2016), no similar system is in place in Canada to benchmark management on dairy farms. The Canadian Bovine Mastitis and Milk Quality Research Network led an initiative to study farms across 6 Canadian provinces to gather data used for mastitis and milk quality research. This latter study, the National Cohort of Dairy Farms (Reyher et al., 2011), followed a cohort of 90 volunteer farms, who practiced milk recording for a year and gathered data on health management, including milking practices. The present study builds upon this work to compare and extend the knowledge of the current state of the Canadian dairy industry.

The National Dairy Study (NDS) 2015 was designed to collect dairy cattle health and management data from dairy farms across all 10 Canadian provinces regardless of participation in milk recording. Targeted data include information about herd demographics, biosecurity, animal care, lameness, calf health and management, reproductive management, and udder health. The objectives of the current study were to quantify the current proportion of adoption of recommended milking practices (RMP) on Canadian dairy farms, and to investigate differences in adoption across region, milking system, herd size, and bulk tank somatic cell count (BTSCC).

\section{MATERIALS AND METHODS}

This project was part of a large national multi-institutional study. Four universities collaborated in this project: University of Guelph, University of Montréal, University of Calgary, and University of Prince Edward Island. Ethical approval was obtained through the Research Ethics Boards from all collaborating universities: the University of Calgary (REB\#14-2481), University of Guelph (REB\#14DC025), University of Montréal (15-007-CERES-D), and University of Prince Edward Island (REB\#6006095). All participants provided informed, written consent.

\section{Questionnaire Development}

The overall NDS project consisted of 2 phases: phase I involved a comprehensive questionnaire developed from the needs assessment conducted in early 2014 (Bauman et al., 2016), and phase II consisted of farm visits to a subset of phase I participants. A literature review was conducted to identify the milking practices reported to have the highest effect on mastitis prevention and control, as well as identifying studies that reported the degree of adoption of these milking practices across the Canadian dairy industry.

The questions used in the udder health section of the questionnaire were adapted from a bilingual questionnaire previously validated by Dufour et al. (2010). The questionnaire can be found on the Canadian Bovine Mastitis and Milk Quality Research Network website under the Publications section (mastitisnetwork.org). It contained questions regarding general milking hygiene and routine, mastitis management on farm, methods of identification of cows with mastitis, and dry-off practices. The milk harvest practices of interest included the use of gloves at milking time, glove disinfection (yes/no), use of premilking teat disinfectant (yes/no), fore-stripping (yes/no), method(s) used to dry teats, use of automatic takeoffs (yes/no), and use of postmilking teat disinfectant (yes/no). The questionnaire was constructed using Qualtrics (2015), an online platform (https://www.qualtrics.com/) for survey design and delivery. The final questionnaire was sent to a 16-person advisory group, made up of stakeholders in the industry (4 producers, 4 veterinarians, 4 researchers, and 4 government representatives) for review and pretesting. After review and subsequent revision, Dairy Farmers of Canada (DFC) translated the questionnaire into French. Three additional bilingual stakeholders further reviewed the translation to ensure the context of the questions was retained. The final bilingual questionnaire was formatted so that it could be completed via multiple formats (online, paper copy, and telephone) to reach as many producers as possible.

To give all producers in Canada $(\sim 12,000)$ the opportunity to complete the questionnaire, a letter of invitation was mailed to all of them. The contact information for all licensed producers in Canada is only available through each provincial marketing board. To maintain the confidentiality of individual dairy producers, each farm was assigned a unique 6-figure code [composed of 2 letters representing each province (e.g., ON, QC, AB) and 4 numbers] and researchers did not have access to contact information. The questionnaire was then administered to all registered Canadian dairy producers in the form of their choice (i.e., online, paper copy, telephone) between March 25 and May 7, 2015. Once the questionnaire was closed, data were exported from Qualtrics (2015) into an Excel spreadsheet for analysis. 
Paper questionnaires and telephone interviews were entered manually into Qualtrics (2015). Participants could voluntarily release their production information (herd size, volume of milk shipped in a year, weighted average SCC) from their respective milk boards for the research team to use. Anonymized data from nonresponders were obtained through each provincial milk board.

\section{Data Analysis}

All statistical analyses were completed using SAS version 9.4 (SAS Institute Inc., Cary, NC). Descriptive statistics were generated for farm demographics and each milking routine variable. Herds with automatic milking systems were excluded from this analysis, as they do not follow a manual milking protocol per se. Herd size was categorized into 3 categories using the first and third quartiles (less than 37 cows, between 37 and 80 cows, more than 80 cows): these categories were chosen to investigate differences in adoption of RMP between "extreme" herds (very small or very large) compared with average-sized herds. The BTSCC in May 2015 was categorized into 2 groups: having a BTSCC of less than 200,000 cells/mL or greater than or equal to 200,000 cells $/ \mathrm{mL}$. This BTSCC was chosen as it was the month of survey administration, and the cutoff for the 2 categories was chosen to look at herds below and above the average BTSCC in Canada, which is approximately 200,000 cells $/ \mathrm{mL}$. Region was defined as 4 categories due to the small number of herds in individual Atlantic and Western provinces. The 4 categories were Western provinces (British Columbia, Alberta, Saskatchewan, Manitoba), Ontario, Québec, and Atlantic provinces, (New Brunswick, Newfoundland, Nova Scotia, and Prince Edward Island).

Chi-squared tests were performed to determine whether explanatory variables, including type of milking system (i.e., tie-stall or parlor), region, herd size, and BTSCC for the month of May, were associated with each of the milking practices described above. Fisher's exact test was used when less than 5 observations per group were expected. Associations were considered significant if the $P$-value of the chi-squared test was less than 0.05. For the herd size and region variables that had more than 2 levels, pairwise comparisons were conducted when the global test of association was significant to identify which levels were different from one another. The chi-squared or Fisher exact tests were used for these pairwise comparisons, and the Bonferroni-Sidak (Abdi, 2007) adjustment was used to adjust for multiple comparisons.

\section{RESULTS}

\section{Descriptive Statistics and Overall Adoption of Milking Practices}

In total, 1,373 dairy producers responded to the survey ( $11 \%$ of all Canadian dairy herds), and 1,193 agreed to participate. Seventy-nine producers (6\%) completed the questionnaire over the telephone, 224 (16\%) completed paper versions, and 1,070 (78\%) completed it online. The regional distribution of the participants was representative of the Canadian dairy farm population. Thirty-five percent of the participants were from Ontario, 43\% from Québec, 13\% from the Western provinces (British Columbia, Alberta, Saskatchewan, Manitoba), and $8 \%$ from the Atlantic provinces (Nova Scotia, Newfoundland, New Brunswick, Prince Edward Island; Table 1). Eighty-six percent of participants were enrolled in milk recording [approximately 12\% above the country average (CDIC, 2015)] and 3\% of participants had certified organic farms. Sixty percent of participants housed their milking cows in tie-stall barns, $38 \%$ in free-stall barns, and $2 \%$ in pack barns. Fifty-nine percent of the herds milked cows with a pipeline system, $29 \%$ in a parlor, and $12 \%$ had automatic milking systems. Farms participating in the study had a mean milking herd size of 74 cows (95\% CI: 70-78), ranging from 10 cows to 1,037 cows, with a first quartile of 37 cows, and third quartile of 80 cows. Farms with automatic milking systems had a mean BTSCC of 208,800 cells/mL (95\% CI: 195,600-221,900) during the month of the study. Farms without an automatic milking system (tie-stall and parlor) had a mean BTSCC of 197,600 cells $/ \mathrm{mL}$ (95\% CI: 191,900-203,300). The difference between the 2 types of farms was statistically significant, although not biologically significant.

Mean yearly volume of milk shipped (in $\mathrm{kg}$ ) was significantly higher in herds participating in the study compared with herds that did not participate (Table 2 ), but the range of production in participant and nonparticipant herds was similar. Average BTSCC for the month of the survey was significantly lower in participating herds compared with nonparticipating herds (Table 2), but again the distribution of BTSCC across participant and nonparticipant herds was similar. Production per province is reported in the Appendix (Table A1). Significant differences were observed in the types of milking system used, depending on region and herd size. Results are reported in the Appendix (Tables A2 and A3). Herds from Ontario and Québec had a significantly higher percentage of tie-stall herds with a pipeline system, whereas Atlantic and Western herds were more likely to have parlor systems $(P<0.0001$; 
Table 1. Number and proportion of total National Dairy Study 2015 participant herds from each Canadian province compared with all Canadian dairy herds ${ }^{1}$

\begin{tabular}{lccccccccccc}
\hline Item & $\mathrm{AB}$ & $\mathrm{BC}$ & $\mathrm{MB}$ & $\mathrm{NB}$ & $\mathrm{NF}$ & $\mathrm{NS}$ & $\mathrm{ON}$ & PEI & QC & SK & Total \\
\hline No. of participating herds (\%) & 59 & 49 & 47 & 28 & 6 & 29 & 420 & 27 & 515 & 13 & 1,193 \\
& $(4.9)$ & $(4.1)$ & $(3.9)$ & $(2.4)$ & $(0.6)$ & $(2.4)$ & $(35.2)$ & $(2.3)$ & $(43.1)$ & $(1.1)$ & \\
& 547 & 437 & 299 & 206 & 32 & 225 & 3,834 & 174 & 5,766 & 163 & 11,683 \\
No. of herds licensed to sell $_{\text {milk in each province }^{2}(\%)}^{(4.7)}$ & $(3.7)$ & $(2.6)$ & $(1.8)$ & $(0.3)$ & $(1.9)$ & $(32.8)$ & $(1.5)$ & $(49.4)$ & $(1.4)$ & \\
\hline
\end{tabular}

${ }^{1} \mathrm{AB}=$ Alberta; $\mathrm{BC}=$ British Columbia; $\mathrm{MB}=$ Manitoba; $\mathrm{NB}=$ New Brunswick; NF = Newfoundland; NS = Nova Scotia; ON = Ontario; PEI $=$ Prince Edward Island; QC = Québec; $\mathrm{SK}=$ Saskatchewan.

${ }^{2}$ Source: Statistics Canada and Canadian Dairy Commission.

Appendix Table A2). Larger herds (>80 cows) were more likely to use a parlor system, whereas medium and small herds were more likely to have a pipeline system $(P<0.0001$; Appendix Table A3).

The overall adoption of milking practices is presented in Table 3. Most participants followed the recommendations for milking procedures, but some were more extensively used than others. For example, postmilking teat disinfection was used by $97 \%$ of the participants, but only $65 \%$ of them used a premilking teat disinfectant (Table 3).

\section{Glove Use During Milking}

Over $60 \%$ of farms reported all milkers on farm wore gloves at milking time, whereas $21 \%$ reported some milkers wore gloves and $15.6 \%$ reported none of the milkers wore gloves (Table 3). Significant associations were observed between the use of gloves by milkers and the type of milking system $(P=0.05$; Table 4$)$. A greater percentage of parlor herds reported that all milkers wear gloves during milking time compared with tie-stalls. Tie-stall herds had a lower proportion of milkers wearing gloves compared with parlor herds $(P=0.05)$. Glove use was also strongly associated with herd size: larger herds (>80 cows) had a higher proportion of milkers wearing gloves compared with medium or smaller size herds (37-80 cows, $<37$ cows; $P=0.02$ ). Likewise, the proportion of smaller herds reporting that none of the milkers wear gloves was higher compared with medium or large herds. Small herds were statistically significantly different in their use of gloves from large herds. Use of gloves in medium-sized herds was not statistically significantly different from small or large herds (Table 4). Glove use in herds was also associated with region: Ontario had a higher proportion of herds that reported no milkers wore gloves compared with Québec herds, Atlantic herds, and Western Canadian herds $(P=0.05)$. Atlantic herds had the highest proportion of herds where all milkers wore gloves (71\%), followed by Western Canadian herds (67\%), Québec herds (65\%), and Ontario herds (59\%). After adjusting for multiple comparisons, we cannot tell which regions are different from one another although the global test indicates that glove use is associated with region. Finally, herd BTSCC was strongly associated with the use of gloves: herds with a BTSCC $\geq 200,000$ cells/mL had a lower proportion of milkers wearing gloves $(P=$ $0.02)$.

\section{Cleaning of Gloves}

Cleaning of gloves was strongly associated with type of milking system and region (Table 5). Although most herds reported cleaning gloves (74\%; 95\% CI: 71-77\%; Table 3), a higher proportion of tie-stall herds reported not cleaning gloves compared with parlor herds $(P<$ 0.001). Regionally, Québec and Ontario had higher proportions of herds not cleaning gloves compared with Atlantic or Western Canadian herds $(P<0.001)$. After

Table 2. Comparison of yearly volume of milk shipped and bulk tank somatic cell count (BTSCC) between participants of the National Dairy Study (NDS) 2015 and nonparticipants

\begin{tabular}{lcc}
\hline Item & $\begin{array}{c}\text { Mean yearly volume of milk shipped, } \mathrm{kg}(95 \% \mathrm{CI}) \\
(1 \mathrm{st}-3 \mathrm{rd} \text { quartile) }\end{array}$ & $\begin{array}{c}\text { BTSCC May 2015, cells } / \mathrm{mL}(95 \% \mathrm{CI}) \\
(\text { st-3rd quartile) }\end{array}$ \\
\hline NDS herds $(\mathrm{n}=1,342)$ & $67,474(66,441-68,506)$ & $191,840(186,850-196,829)$ \\
& $(30,428-76,002)$ & $(131,000-238,000)$ \\
Non-NDS herds $(\mathrm{n}=10,341)^{1}$ & $56,011(55,718-56,303)$ & $206,212(204,413-208,010)$ \\
& $(26,573-62,488)$ & $(140,000-260,000)$ \\
test $P$-value & $<0.001$ & $<0.001$ \\
\hline
\end{tabular}

${ }^{1}$ Source: Provincial milk marketing boards. 
adjusting for multiple comparisons, cleaning of gloves was statistically significantly different in Québec compared with Western Canada. No difference was seen between Ontario and Québec, and between Atlantic and Western Canadian herds (Table 5). Cleaning of gloves, however, was not significantly associated with herd size or herd BTSCC.

\section{Use of Premilking Teat Disinfectant}

Just over two-thirds of participants in the study reported using premilking teat disinfection $(64 \% ; 95 \%$ CI: $61-67 \%$; Table 3 ). Use of predisinfection was strongly associated with milking system, herd size, and region in the current study (Table 6). A higher proportion of parlor herds used predisinfection compared with tie-stall herds $(P<0.0001)$, and larger herds also had higher proportion of use of predisinfection compared with medium or smaller herds $(75 \%$ vs. $62 \%$ and $60 \%$; $P<0.001)$. Although the overall test indicates that use of premilking teat disinfection is associated with herd, we cannot tell which herds sizes are different from one another, after adjusting for multiple comparisons. Regionally, the Atlantic region had a higher proportion of herds using predisinfection ( $82 \%$ ) followed by herds in Ontario (75\%). Western and Québec herds had lower proportions of the use of predisinfection during milking preparation (62 and 54\%, respectively; $P<0.0001$ ).

Table 3. Proportion of adoption of recommended milking practices of 1,342 participants of the National Dairy Study 2015 (n represents the number of respondents who answered that question)

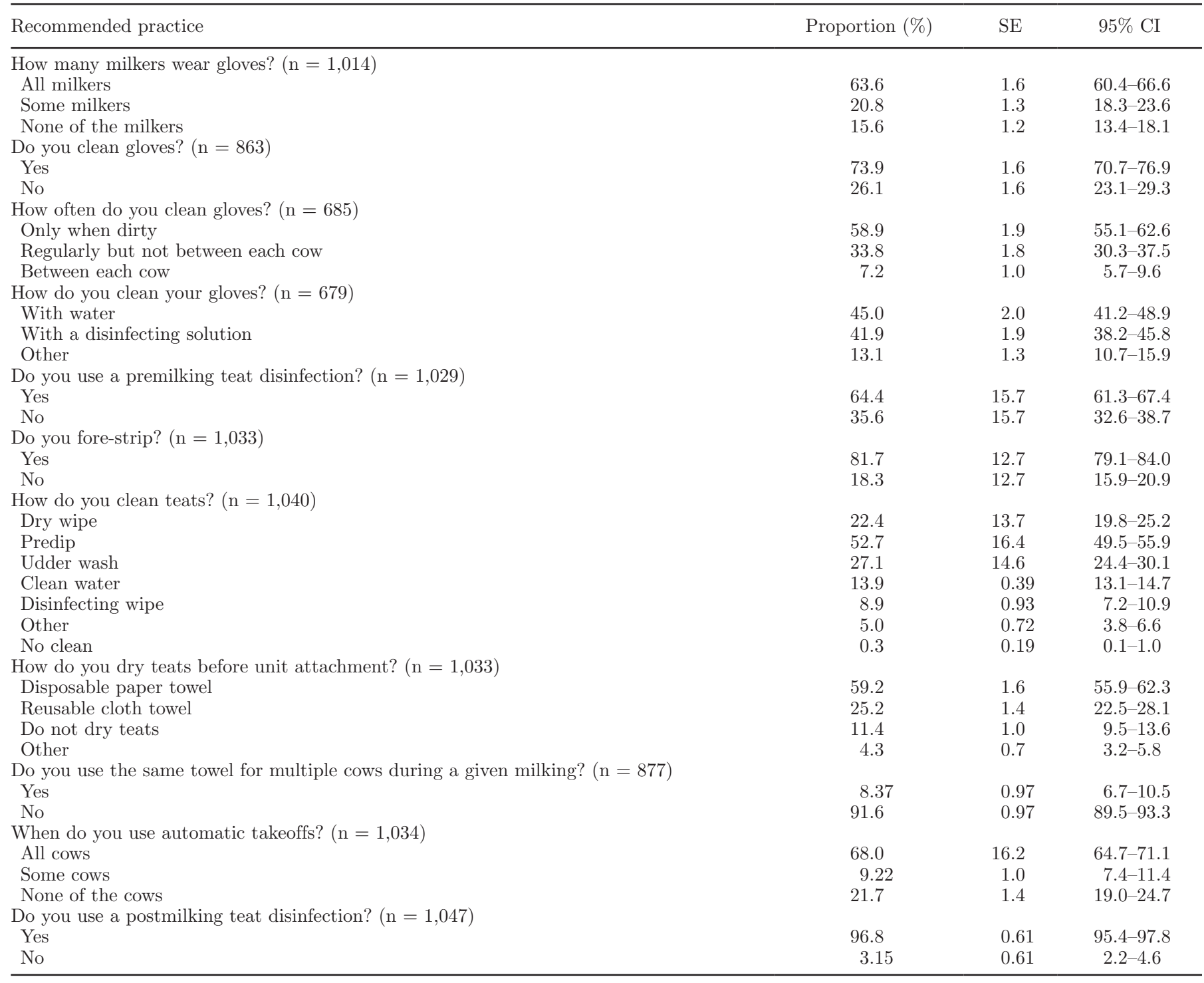


Table 4. Simple associations between glove use and milking system, herd size, region, and bulk tank SCC in 1,342 herds participating in of the National Dairy Study 2015

\begin{tabular}{|c|c|c|c|c|}
\hline \multirow[b]{2}{*}{ Item } & \multicolumn{3}{|c|}{ Do milkers wear gloves during milking? } & \multirow[b]{2}{*}{$P$-value } \\
\hline & $\begin{array}{c}\text { No milkers, } \\
\% \text { (no.) }\end{array}$ & $\begin{array}{c}\text { Some milkers, } \\
\% \text { (no.) }\end{array}$ & $\begin{array}{l}\text { All milkers, } \\
\% \text { (no.) }\end{array}$ & \\
\hline Milking system & & & & 0.05 \\
\hline Tie-stall & $16(101)$ & $23(143)$ & $61(382)$ & \\
\hline Parlor & $14(45)$ & $17(52)$ & $69(212)$ & \\
\hline Total & $16(146)$ & $21(195)$ & $63(594)$ & \\
\hline Herd size & & & & 0.02 \\
\hline$<37^{\mathrm{a}}$ & $19(55)$ & $19(55)$ & $62(174)$ & \\
\hline $37-80^{\mathrm{ab}}$ & $16(68)$ & $23(101)$ & $61(263)$ & \\
\hline$>80^{\mathrm{b}}$ & $11(23)$ & $17(39)$ & $72(158)$ & \\
\hline Total & $16(146)$ & $21(195)$ & $64(595)$ & \\
\hline Region & & & & 0.05 \\
\hline Ontario $^{a}$ & $20(65)$ & $21(69)$ & $59(191)$ & \\
\hline Québec $^{\mathrm{a}}$ & $12(52)$ & $23(94)$ & $65(272)$ & \\
\hline Atlantic $^{\mathrm{a}}$ & $17(12)$ & $12(9)$ & $71(52)$ & \\
\hline Western $^{a}$ & $14(17)$ & $19(23)$ & $67(80)$ & \\
\hline Total & $16(146)$ & $21(195)$ & $63(595)$ & \\
\hline Bulk tank SCC & & & & 0.02 \\
\hline$<200,000$ cells $/ \mathrm{mL}$ & $14(80)$ & $22(123)$ & $64(399)$ & \\
\hline$\geq 200,000$ cells $/ \mathrm{mL}$ & $19(66)$ & $19(72)$ & $62(196)$ & \\
\hline Total & $16(146)$ & 21 (195) & $63(595)$ & \\
\hline
\end{tabular}

${ }^{a, b}$ For herd size and region, levels with different superscripts differed significantly after Bonferroni-Sidak adjustment for multiple comparisons.

Ontario and Atlantic herds were significantly different from Western and Québec herds in their use of premilking disinfection. No association was present between use of predisinfection and herd BTSCC $(P=0.83)$.

Table 5. Simple associations between glove hygiene milking system, herd size, region, and bulk tank SCC in 1,342 herds participating in the National Dairy Study 2015

\begin{tabular}{|c|c|c|c|}
\hline \multirow[b]{2}{*}{ Item } & \multicolumn{2}{|c|}{$\begin{array}{l}\text { Do milkers } \\
\text { clean gloves? }\end{array}$} & \multirow[b]{2}{*}{$P$-value } \\
\hline & $\begin{array}{c}\text { Yes, } \\
\% \text { (no.) }\end{array}$ & $\begin{array}{c}\text { No, } \\
\% \text { (no.) }\end{array}$ & \\
\hline Milking system & & & $<0.001$ \\
\hline Tie-stall & $70(349)$ & $33(172)$ & \\
\hline Parlor & $88(230)$ & $12(32)$ & \\
\hline Total & $74(579)$ & $26(204)$ & \\
\hline Herd size & & & 0.10 \\
\hline$<37$ & $74(167)$ & $26(60)$ & \\
\hline $37-80$ & $71(257)$ & $29(104)$ & \\
\hline$>80$ & $79(155)$ & $21(40)$ & \\
\hline Total & $74(579)$ & $26(204)$ & \\
\hline Region & & & $<0.001$ \\
\hline Ontario $^{\mathrm{ab}}$ & $73(186)$ & $27(70)$ & \\
\hline Québec $^{\mathrm{a}}$ & $68(249)$ & $32(115)$ & \\
\hline Atlantic $^{\mathrm{bc}}$ & $87(52)$ & $13(8)$ & \\
\hline Western $^{\mathrm{c}}$ & $89(92)$ & $11(11)$ & \\
\hline Total & $74(579)$ & $26(204)$ & \\
\hline Bulk tank SCC & & & 0.93 \\
\hline$<200,000$ cells $/ \mathrm{mL}$ & $75(385)$ & $25(135)$ & \\
\hline$\geq 200,000$ cells $/ \mathrm{mL}$ & $74(194)$ & $26(69)$ & \\
\hline Total & $74(579)$ & $26(204)$ & \\
\hline
\end{tabular}

${ }^{\mathrm{a}-\mathrm{c}}$ For region, levels with different superscripts differed significantly after Bonferroni-Sidak adjustment for multiple comparisons.

\section{Fore-Stripping}

Overall, $82 \%$ of participants reported fore-stripping during milking preparation (Table 3). No associations

Table 6. Simple associations between use of premilking teat disinfection and milking system, herd size, region, and bulk tank SCC in 1,342 herds participating in the National Dairy Study 2015

\begin{tabular}{|c|c|c|c|}
\hline \multirow[b]{2}{*}{ Item } & \multicolumn{2}{|c|}{$\begin{array}{l}\text { Do you use premilking } \\
\text { teat disinfection? }\end{array}$} & \multirow[b]{2}{*}{$P$-value } \\
\hline & $\begin{array}{c}\text { Yes, } \\
\%(\text { no.) }\end{array}$ & $\begin{array}{c}\text { No, } \\
\% \text { (no.) }\end{array}$ & \\
\hline Milking system & & & $<0.0001$ \\
\hline Tie-stall & $58(360)$ & $42(264)$ & \\
\hline Parlor & $78(240)$ & $22(68)$ & \\
\hline Total & $64(601)$ & $36(332)$ & \\
\hline Herd size & & & 0.001 \\
\hline$<37^{\mathrm{a}}$ & $60(171)$ & $40(113)$ & \\
\hline $37-80^{\mathrm{a}}$ & $62(266)$ & $38(164)$ & \\
\hline$>80^{\mathrm{b}}$ & $75(164)$ & $25(55)$ & \\
\hline Total & $64(601)$ & $36(332)$ & \\
\hline Region & & & $<0.0001$ \\
\hline Ontario $^{\mathrm{a}}$ & $75(242)$ & $25(80)$ & \\
\hline Québec ${ }^{\mathrm{b}}$ & $54(225)$ & $46(193)$ & \\
\hline Atlantic ${ }^{\mathrm{a}}$ & $82(60)$ & $18(13)$ & \\
\hline Western $^{\mathrm{b}}$ & $62(74)$ & $38(46)$ & \\
\hline Total & $64(601)$ & $36(332)$ & \\
\hline Bulk tank SCC & & & 0.83 \\
\hline$<200,000$ cells $/ \mathrm{mL}$ & $64(387)$ & $36(214)$ & \\
\hline$\geq 200,000$ cells $/ \mathrm{mL}$ & $64(214)$ & $36(118)$ & \\
\hline Total & $64(601)$ & $36(332)$ & \\
\hline
\end{tabular}

$\overline{a, b}$ For herd size and region, levels with different superscripts differed significantly after Bonferroni-Sidak adjustment for multiple comparisons. 
Table 7. Simple associations between fore-stripping during milking preparation and milking system, herd size, region, and bulk tank SCC in 1,342 herds participating in the National Dairy Study 2015

\begin{tabular}{|c|c|c|c|}
\hline \multirow[b]{2}{*}{ Item } & \multicolumn{2}{|c|}{ Do you fore-strip? } & \multirow[b]{2}{*}{$P$-value } \\
\hline & $\begin{array}{c}\text { Yes, } \\
\% \text { (no.) }\end{array}$ & $\begin{array}{c}\text { No, } \\
\% \text { (no.) }\end{array}$ & \\
\hline Milking system & & & 0.72 \\
\hline Tie-stall & $82(513)$ & $18(112)$ & \\
\hline Parlor & $81(249)$ & $19(58)$ & \\
\hline Total & $82(762)$ & $18(170)$ & \\
\hline Herd size & & & 0.82 \\
\hline$<37$ & $82(234)$ & $18(50)$ & \\
\hline $37-80$ & $82(353)$ & $18(78)$ & \\
\hline$>80$ & $80(175)$ & $20(43)$ & \\
\hline Total & $82(762)$ & $18(171)$ & \\
\hline Region & & & 0.18 \\
\hline Ontario & $82(264)$ & $18(58)$ & \\
\hline Québec & $83(345)$ & $17(73)$ & \\
\hline Atlantic & $86(63)$ & $14(10)$ & \\
\hline Western & $75(90)$ & $25(30)$ & \\
\hline Total & $82(762)$ & $18(171)$ & \\
\hline Bulk tank SCC & & & 0.13 \\
\hline$<200,000$ cells $/ \mathrm{mL}$ & $80(483)$ & $20(119)$ & \\
\hline$\geq 200,000$ cells $/ \mathrm{mL}$ & $84(279)$ & $16(52)$ & \\
\hline $\bar{T}$ otal & $82(762)$ & $18(171)$ & \\
\hline
\end{tabular}

were present between fore-stripping and milking system $(P=0.72)$, herd size $(P=0.82)$, region $(P=0.18)$, or BTSCC $(P=0.13$; Table 7$)$.

\section{Drying Teats}

Overall, $88 \%$ of herds reported using some method to dry teats before unit attachment; $59 \%$ reported using a disposable paper towel, $25 \%$ used a reusable cloth towel, and $4 \%$ use other methods to dry (Table 3). Only 106 herds $(12 \%)$ reported not drying teats. Method of drying teats was strongly associated with milking system, herd size, and region in this study (Table 8). A higher proportion of tie-stall herds reported using disposable paper towels to dry teats before unit attachment than parlor herds $(P<0.0001)$. Parlor herds had a higher proportion of use of reusable towels compared with tie-stall herds $(P<0.0001)$. Both milking systems had similar likelihood not to dry teats or to use another method of drying (Table 8). A higher proportion of small and medium-sized herds used disposable paper towels compared with larger herds $(P<0.0001)$. Large herds had a higher proportion of use of reusable towels for drying over any other method $(P<0.0001)$. Larger herds were significantly different from small and medium herds in their method of drying teats (Table 8). A significant association was present between region and method of drying teats $(P<0.0001)$. A higher proportion of herds in Québec reported using disposable paper towels compared with Ontario, Atlantic, and
Western herds (Table 8). After adjusting for multiple comparisons, Québec was significantly different from the rest of the regions. No significant association was seen in this study between drying teats before unit attachment and herd BTSCC $(P=0.30)$, although less than $10 \%$ of participants reported using the same towel to dry multiple cows during a given milking $(8 \% ; 95 \%$ CI: $7-11 \%$; Table 3 ).

\section{Use of Automatic Takeoffs}

The majority of farms in this study reported using automatic takeoffs, $78.3 \%$ of farms used them with all or some of the cows, whereas only $22 \%$ reporting not using them at all (95\% CI: 19-25\%; Table 3). The use of automatic takeoffs was associated with milking system, herd size, and region (Table 9). Parlors reportedly had a higher proportion of use of automatic takeoffs compared with tie-stalls $(P<0.0001)$; medium and large herds had a higher proportion of use of automatic takeoffs compared with smaller herds $(P<0.0001)$. After adjusting for multiple comparisons, all 3 herd sizes were different significantly from one another (Table 9). Herds from Québec and the Western provinces had a higher proportion of use of automatic takeoffs than herds from Ontario and the Atlantic provinces $(P<$ 0.0001). Herds in Western Canada differed significantly from all other regions, and Ontario and Québec different significantly from one another (Table 9). No association was observed between herd BTSCC levels and the use of automatic takeoffs $(P=0.93)$.

\section{Postmilking Teat Disinfection}

Postmilking teat disinfection was adopted by the vast majority of participants: $97 \%$ reported using a postmilking disinfection method (Table 3). It was not significantly associated with milking system, herd size, or herd BTSCC, likely due to lack of variability. A significant association was seen with region using a Fisher's exact test $(P=0.04$; Table 10$)$, but the effect is not meaningful as all regions had between 95 and $99 \%$ adoption of this practice.

\section{DISCUSSION}

The provincial distribution, housing system, and milking system among study participants was similar to the national population, and compared with nonparticipant herds, participants had a higher milk production but similar milk quality (NDS herds shipped on average $11,000 \mathrm{~kg}$ of milk per year more than non-NDS herds, and had an average BTSCC lower than non- 
Table 8. Simple associations between teat-drying methods during milking preparation and milking system, herd size, region, and bulk tank SCC in 1,342 herds participating in the National Dairy Study 2015

\begin{tabular}{|c|c|c|c|c|c|}
\hline \multirow[b]{2}{*}{ Item } & \multicolumn{4}{|c|}{ How do you dry teats before milking? } & \multirow[b]{2}{*}{$P$-value } \\
\hline & $\begin{array}{c}\text { Disposable } \\
\text { towel, \% (no.) }\end{array}$ & $\begin{array}{c}\text { Reusable } \\
\text { towel, \% (no.) }\end{array}$ & $\begin{array}{l}\text { Do not dry, } \\
\% \text { (no.) }\end{array}$ & $\begin{array}{l}\text { Other, } \\
\% \text { (no.) }\end{array}$ & \\
\hline Milking system & & & & & $<0.0001$ \\
\hline Tie-stall & $72(449)$ & $11(70)$ & $13(82)$ & $4(25)$ & \\
\hline Parlor & $34(103)$ & $54(165)$ & $8(24)$ & $4(14)$ & \\
\hline Total & $59(552)$ & $25(235)$ & $12(106)$ & $4(39)$ & \\
\hline Herd size & & & & & $<0.0001$ \\
\hline$<37^{\mathrm{a}}$ & $69(197)$ & $13(36)$ & $12(35)$ & $6(16)$ & \\
\hline $37-80^{\mathrm{a}}$ & $63(273)$ & $20(87)$ & $13(54)$ & $4(16)$ & \\
\hline$>80^{\mathrm{b}}$ & $37(82)$ & $51(112)$ & $8(17)$ & $4(8)$ & \\
\hline Total & $59(552)$ & $25(235)$ & $12(106)$ & $4(40)$ & \\
\hline Region & & & & & $<0.0001$ \\
\hline Ontario $^{a}$ & $46(148)$ & $38(122)$ & $9(29)$ & $7(23)$ & \\
\hline Québec $^{\mathrm{b}}$ & $78(326)$ & $6(27)$ & $14(57)$ & $2(8)$ & \\
\hline Atlantic $^{\mathrm{a}}$ & $37(27)$ & $49(10)$ & $8(6)$ & $6(4)$ & \\
\hline Western $^{\mathrm{a}}$ & $42(51)$ & $42(50)$ & $12(14)$ & $4(5)$ & \\
\hline Total & $59(552)$ & $25(235)$ & $12(106)$ & $4(40)$ & \\
\hline Bulk tank SCC & & & & & 0.30 \\
\hline$<200,000$ cells $/ \mathrm{mL}$ & $57(342)$ & $27(119)$ & $12(70)$ & $4(26)$ & \\
\hline$\geq 200,000$ cells $/ \mathrm{mL}$ & $63(210)$ & $22(52)$ & $11(36)$ & $4(14)$ & \\
\hline Total & $59(552)$ & $25(235)$ & $12(106)$ & $4(40)$ & \\
\hline
\end{tabular}

${ }^{a, b}$ For herd size and region, levels with different superscripts differed significantly after Bonferroni-Sidak adjustment for multiple comparisons.

NDS herds by approximately 14,000 cells/mL only). Although the means were significantly different, the distributions or ranges were similar and so cover the range of production and BTSCC in the country. Survey

Table 9. Simple associations between use of automatic takeoffs during milking and milking system, herd size, region, and bulk tank SCC in 1,342 herds participating in the National Dairy Study 2015

\begin{tabular}{|c|c|c|c|}
\hline \multirow[b]{2}{*}{ Item } & \multicolumn{2}{|c|}{$\begin{array}{l}\text { Do you use automatic } \\
\text { takeoffs for most or all cows? }\end{array}$} & \multirow[b]{2}{*}{$P$-value } \\
\hline & $\begin{array}{l}\text { Yes, } \\
\% \text { (no.) }\end{array}$ & $\begin{array}{c}\text { No, } \\
\%(\text { no.) }\end{array}$ & \\
\hline Milking system & & & $<0.0001$ \\
\hline Tie-stall & $70(480)$ & $30(201)$ & \\
\hline Parlor & $94(321)$ & $6(19)$ & \\
\hline Total & $78(801)$ & $22(220)$ & \\
\hline Herd size & & & $<0.0001$ \\
\hline$<37^{\mathrm{a}}$ & $61(190)$ & $39(123)$ & \\
\hline $37-80^{\mathrm{b}}$ & $80(376)$ & $20(92)$ & \\
\hline$>80^{\mathrm{c}}$ & $98(240)$ & $2(6)$ & \\
\hline Total & $78(806)$ & $22(221)$ & \\
\hline Region & & & $<0.0001$ \\
\hline Ontario $^{a}$ & $70(247)$ & $30(104)$ & \\
\hline Québec $^{\text {b }}$ & $82(379)$ & $18(82)$ & \\
\hline Atlantic $^{\mathrm{ab}}$ & $70(57)$ & $30(24)$ & \\
\hline Western $^{c}$ & $92(123)$ & $8(11)$ & \\
\hline Total & $78(806)$ & $22(221)$ & \\
\hline Bulk tank SCC & & & 0.93 \\
\hline$<200,000$ cells $/ \mathrm{mL}$ & $81(583)$ & $19(138)$ & \\
\hline$\geq 200,000$ cells $/ \mathrm{mL}$ & $81(346)$ & $19(83)$ & \\
\hline $\bar{T}$ otal & $81(929)$ & $20(221)$ & \\
\hline
\end{tabular}

\footnotetext{
${ }^{a-c}$ For herd size and region, levels with different superscripts differed significantly after Bonferroni-Sidak adjustment for multiple comparisons.
}

participants therefore likely represent the Canadian population quite well.

The adoption of RMP varied across farms, with markedly different adoption patterns for different prac-

Table 10. Simple associations between use of postmilking disinfectant after milking and milking system, herd size, region, and bulk tank SCC in 1,342 herds participating in the National Dairy Study 2015

\begin{tabular}{|c|c|c|c|}
\hline \multirow[b]{2}{*}{ Item } & \multicolumn{2}{|c|}{$\begin{array}{c}\text { Do you use postmilking } \\
\text { disinfectant? }\end{array}$} & \multirow[b]{2}{*}{$P$-value } \\
\hline & $\begin{array}{c}\text { Yes, } \\
\% \text { (no.) }\end{array}$ & $\begin{array}{c}\text { No, } \\
\% \text { (no.) }\end{array}$ & \\
\hline Milking system & & & 0.91 \\
\hline Tie-stall & $97(604)$ & $3(19)$ & \\
\hline Parlor & $97(299)$ & $3(9)$ & \\
\hline Total & $97(903)$ & $3(28)$ & \\
\hline Herd size & & & 0.53 \\
\hline$<37$ & $96(272)$ & $4(10)$ & \\
\hline $37-80$ & $98(420)$ & $2(10)$ & \\
\hline$>80$ & $96(212)$ & $4(8)$ & \\
\hline Total & $97(904)$ & $3(28)$ & \\
\hline Region & & & $0.04^{1}$ \\
\hline Ontario $^{a}$ & $95(308)$ & $5(15)$ & \\
\hline Québec $^{\mathrm{b}}$ & $99(412)$ & $1(5)$ & \\
\hline Atlantic $^{\mathrm{ab}}$ & $96(70)$ & $4(3)$ & \\
\hline Western $^{\mathrm{ab}}$ & $96(114)$ & $4(5)$ & \\
\hline Total & $97(904)$ & $3(28)$ & \\
\hline Bulk tank SCC & & & 0.11 \\
\hline$<200,000$ cells $/ \mathrm{mL}$ & $98(585)$ & $2(14)$ & \\
\hline$\geq 200,000$ cells $/ \mathrm{mL}$ & $96(319)$ & $4(14)$ & \\
\hline Total & $97(904)$ & $3(28)$ & \\
\hline
\end{tabular}

${ }^{a, b}$ For region, levels with different superscripts differed significantly after Bonferroni-Sidak adjustment for multiple comparisons.

${ }^{1}$ Fisher's exact test. 
tices. Some of the practices, most notably the use of a postmilking teat disinfectant, were reported to be widely adopted. Other practices, including cleaning gloves with disinfectant and use of a premilking teat disinfectant, were much less widely used. Our findings of the overall adoption of practices were similar to previous Canadian studies (Dufour et al., 2011; Reyher et al., 2011). The overall adoption of practices including use of gloves, glove disinfection and frequency, use of premilking disinfectant, teat cleaning and drying methods, use of automatic takeoffs, and use of postmilking teat disinfectant were comparable to previously reported values (Reyher et al., 2011). The only notable difference observed was a higher use of fore-stripping in the present study ( $81 \%$ of farms) compared with $61 \%$ in a 2007-2008 report by Reyher et al. (2011).

Findings from this study can shed light on some of the previous findings by Olde Riekerink et al. (2008). The differences in IRCM between Western Canadian herds and Ontario and Québec herds could be due to differences in adoption of certain milking practices, such as the use of gloves during milking, cleaning gloves, and use of a premilking disinfectant. Western Canadian herds were overall more likely to adopt the RMP compared with Ontario and Québec herds, which could explain in part why they had a lower mean IRCM (7.6 to 20.2 cases per 100 cow-years versus 31.6 and 29.7 cases per 100 cow-years; Olde Riekerink et al., 2008). For example, decreased incidence of mastitis due to Staphylococcus aureus has been related to the use of individual towels to dry teats, fore-stripping during milking preparation, and use of postmilking teat disinfectant (Barkema et al., 1999). Similarly, Dufour et al., (2012) found the use of premilking teat disinfectant was successful in preventing infections from contagious pathogens. However, for premilking teat disinfectant to prevent new IMI, it is important to maintain cup hygiene (Barnouin et al., 2004). Still, only $65 \%$ of Canadian producers surveyed here reported using a premilking teat disinfectant, and its use was highly associated with milking system, herd size, and region. Parlor herds, herds with more than 80 cows, and herds in Ontario and the Atlantic Provinces reported a higher use of premilking disinfectant than the rest of the herds in the study. No significant association was observed between the use of premilking teat disinfectant and herd BTSCC level in this study, which may reflect the cross-sectional design of the study. Participants were not asked how long they had been using a premilking disinfectant, and it is not possible to determine if participants were using a premilking disinfectant because they had a high BTSCC and were looking to control it, or they had a low BTSCC because they had been using a premilking disinfectant, which might explain the lack of association.

The use of gloves during milking and the use of premilking teat disinfectant have been shown elsewhere to decrease the incidence of IMI by S. aureus (Dufour et al., 2012). It is possible that herds with specific pathogens issues like contagious mastitis could see an improvement in udder health and IMI incidence if these practices are implemented correctly into the milking routine. Over half of the participants report using a premilking teat disinfectant, or using udder wash as a method to clean teats before unit attachment (Table 3). However, one-third of producers reported using just a dry wipe or water without disinfectant to clean teats. This is concerning as a key element of mastitis prevention is cleaning teats completely before milk harvest to remove bacteria that could be present on the skin surface of the teat. This practice is also a required element of the Canadian Quality Milk program (an on-farm food safety program created by Dairy Farmers of Canada). Producers must use an approved teat-sanitizing product before milking. Using a nondisinfectant method to clean teats during milking preparation does not ensure the bacteria are being removed and could compromise the efforts to prevent new IMI.

Studies have also shown the importance of drying teats before unit attachment (Elmoslemany et al., 2010). Eleven percent of participants in the present survey reported not applying this practice (Table 3). The type of towel used for drying was highly associated with milking system, region, and herd size. Disposable paper towels were more likely to be used by tie-stall herds, small to medium size herds, and herds from the province of Québec, whereas reusable cloth towels were more likely to be used in parlors, larger herds, and herds from all other provinces but Québec. These findings might be explained by looking at the distribution of milking systems across the country (Appendix Table A2). Québec has the majority of tie-stall herds, and using disposable towels is a more practical way to dry teats because producers do not have to carry containers with clean and dirty towels while moving milking units through the barn. Larger herds were mainly parlor herds, whereas small and medium-sized herds were more likely to be tie-stall herds (Appendix Table A3). The farm's milking system may influence which practices are adopted or not on farms across the country, as the type of milking systems are vastly different across regions and herd sizes (tie-stalls are predominant in Ontario and Québec, free-stalls are predominant in Western Canada and Atlantic provinces). We cannot tease apart whether the differences in adoption of RMP is due to the physical characteristics of each milking 
system, or due to cultural factors from different regions because both variables were highly correlated in this data set.

Although fore-stripping is important to decrease the incidence of contagious pathogens, it also plays a role during milking preparation to stimulate milk letdown and identify animals with clinical mastitis infections. Stimulation of the teats leads to the release of oxytocin, which results in expulsion of milk from the udder (Bruckmaier and Blum, 1996). This is important for complete milk-out as well as preventing teat damage and hyperkeratosis, and it is a mandatory practice in Canada under the Canadian Quality Milk program. Producers are required to inspect the milk of each cow before it can be added to the bulk tank. However, a significant proportion of Canadian producers did not fore-strip during milking preparation $(\sim 19 \%)$ and are therefore not complying with mandatory practices. This in turn can potentially lead to producers missing cows with clinical signs of infection, increased SCC in milk, and risk of transmission of contagious pathogens. We did not observe any specific associations between farm characteristics and the inclusion of fore-stripping into the milking routine.

Dufour et al. (2011) found in their review that a properly adjusted milking unit, as well as the use of automatic takeoffs, were essential practices during milking and had an effect on SCC. Over-milking also causes teat tissue damage or injury, which can have long-term consequences on udder health of older cows. Studies suggest that over-milking should be minimized as much as possible to preserve teat-end health (Edwards et al., 2013). Yet, over $20 \%$ of participants here reported not using automatic takeoffs at all.

Premilking teat preparation is only successful in preventing IMI when carried out properly and if all the elements are used together to ensure proper teat hygiene. The effectiveness of the practices is diminished when one or more of the aforementioned practices are not used properly or at all. Therefore, it is important for producers to implement a complete and correct routine to maximize their preventive efforts against mastitis.

Overall, the majority of Canadian dairy producers seem to comply with most of the recommendations for milking preparation practices. However, some key elements of milking routines that are important for mastitis prevention are not adopted as widely as others (premilking teat disinfectant, fore-stripping, use of automatic takeoffs), even though most of the milking practices are relatively inexpensive and can easily be implemented on farm. It would be helpful to explore the reasons why producers choose to adopt or ignore RMP (e.g., lack of knowledge, lack of motivation, perceived efficacy, perceived mastitis risk).

\section{ACKNOWLEDGMENTS}

The authors thank Sam Deleen, Julia Nguyen, Sabrina Van Schyndel, Chantal Stoop, Jennifer Reynen from the University of Guelph, Guelph, Ontario, Canada, and all students and technicians who helped collect data during farm visits across all provinces. Thank you to the participating producers for making this research possible. This project was part of the Canadian Bovine Mastitis and Milk Quality Research Network program, funded by Dairy Farmers of Canada and Agriculture and Agri-Food Canada through the Dairy Research Cluster 2 Program, Dairy Farmers of Ontario (Mississauga, ON, Canada), the Ontario Veterinary College (University of Guelph), and the Ontario Ministry of Agriculture, Food and Rural Affairs. The first author (E.B.) was also supported by the Natural Science and Engineering Research Council of Canada-Collaborative Research and Training Experience Program, Canada, milk quality scholarship.

\section{REFERENCES}

Abdi, H. 2007. Bonferroni and Šidak corrections for multiple comparisons. Pages 103-106 in Encyclopedia of Measurement and Statistics. N. J. Salkind, ed. Sage Publications Inc., Thousand Oaks, CA.

Barkema, H. W., Y. H. Schukken, T. J. G. M. Lam, M. L. Beiboer, G. Benedictus, and A. Brand. 1998. Management practices associated with low, medium, and high somatic cell counts in bulk milk. J. Dairy Sci. 81:1917-1927.

Barkema, H. W., J. D. Van Der Ploeg, Y. H. Schukken, T. J. G. M. Lam, M. L. Beiboer, G. Benedictus, and A. Brand. 1999. Management style and its association with bulk milk somatic cell count and incidence rate of clinical mastitis. J. Dairy Sci. 82:1655-1663.

Barnouin, J., M. Chassagne, S. Bazin, and D. Boichard. 2004. Management practices from questionnaire surveys in herds with very low somatic cell score through a national mastitis program in France. J. Dairy Sci. 87:3989-3999.

Bauman, C. A., H. W. Barkema, J. Dubuc, G. P. Keefe, and D. F Kelton. 2016. Identifying management and disease priorities of Canadian dairy industry stakeholders. J. Dairy Sci. 99:10194-10203.

Bruckmaier, R. M., and J. W. Blum. 1996. Simultaneous recording of oxytocin release, milk ejection and milk flow during milking of dairy cows with and without prestimulation. J. Dairy Res. 63:201208.

Canadian Dairy Commission. 2016. The Industry. Accessed Jul. 17, 2016. http://www.cdc-ccl.gc.ca/CDC/index-eng.php?id=3796.

Canadian Dairy Information Center (CDIC). 2015. Number of Farms, Dairy Cows and Heifers. Accessed Jul. 17, 2016. http://www. dairyinfo.gc.ca/index_e.php?s1=dff-fcil\&s $2=$ farm-ferme\&s $3=n b$.

Chassagne, M., J. Barnouin, and M. Le Guenic. 2005. Expert assessment study of milking and hygiene practices characterizing very low somatic cell score herds in France. J. Dairy Sci. 88:1909-1916.

Dufour, S., H. W. Barkema, L. DesCôteaux, T. J. DeVries, I. R. Dohoo, K. K. Reyher, J. P. Roy, and D. T. Scholl. 2010. Development and validation of a bilingual questionnaire for measuring udder health related management practices on dairy farms. Prev. Vet. Med. 95:74-85.

Dufour, S., I. R. Dohoo, H. W. Barkema, L. DesCôteaux, T. J. DeVries, K. K. Reyher, J. P. Roy, and D. T. Scholl. 2012. Manageable risk factors associated with the lactational incidence, elimination, and prevalence of Staphylococcus aureus intramammary infections in dairy cows. J. Dairy Sci. 95:1283-1300. 
Dufour, S., A. Fréchette, H. W. Barkema, A. Mussell, and D. T. Scholl. 2011. Invited review: Effect of udder health management practices on herd somatic cell count. J. Dairy Sci. 94:563-579.

Edwards, J. P., B. O'Brien, N. Lopez-Villalobos, and J. G. Jago. 2013. Overmilking causes deterioration in teat-end condition of dairy cows in late lactation. J. Dairy Res. 80:344-348.

Elmoslemany, A. M., G. P. Keefe, I. R. Dohoo, J. J. Wichtel, H. Stryhn, and R. T. Dingwell. 2010. The association between bulk tank milk analysis for raw milk quality and on-farm management practices. Prev. Vet. Med. 95:32-40.

McLaren, C. J., K. D. Lissemore, T. F. Duffield, K. E. Leslie, D. F. Kelton, and B. Grexton. 2006. The relationship between herd level disease incidence and a return over feed index in Ontario dairy herds. Can. Vet. J. 47:767-773.

Olde Riekerink, R. G. M., H. W. Barkema, D. F. Kelton, and D. T. Scholl. 2008. Incidence rate of clinical mastitis on Canadian dairy farms. J. Dairy Sci. 91:1366-1377.
Reyher, K. K., S. Dufour, H. W. Barkema, L. Des Côteaux, T. J. DeVries, I. R. Dohoo, G. P. Keefe, J. P. Roy, and D. T. Scholl. 2011. The National Cohort of Dairy Farms - A data collection platform for mastitis research in Canada. J. Dairy Sci. 94:1616-1626.

Sargeant, J. M., H. M. Scott, K. E. Leslie, M. J. Ireland, and A. Bashiri. 1998. Clinical mastitis in dairy cattle in Ontario: Frequency of occurrence and bacteriological isolates. Can. Vet. J. 39:33-38.

USDA-APHIS. 2016. About NAHMS. Accessed Jul. 17, 2016. https:// www.aphis.usda.gov/aphis/ourfocus/animalhealth/monitoringand-surveillance/nahms/about.

van Dorp, R. T., S. W. Martin, M. M. Shoukri, J. P. Noordhuizen, and J. C. Dekkers. 1999. An epidemiologic study of disease in 32 registered Holstein dairy herds in British Columbia. Can. J. Vet. Res. 63:185-192.

\section{APPENDIX}

Table A1. Average production values per province for National Dairy Study 2015 participants

\begin{tabular}{lrccc}
\hline Province & $\begin{array}{c}\text { Average total } \\
\text { milk/mo }(\mathrm{kg})\end{array}$ & $\begin{array}{c}\text { Average } \\
\text { fat }(\%)\end{array}$ & $\begin{array}{c}\text { Average } \\
\text { protein (\%) }\end{array}$ & $\begin{array}{c}\text { Average bulk tank } \\
\text { SCC (cells } / \mathrm{mL})\end{array}$ \\
\hline British Columbia $(\mathrm{n}=49)$ & 124,343 & 3.97 & 3.33 & 157,835 \\
Alberta $(\mathrm{n}=59)$ & 120,340 & 4.02 & 3.29 & 174,634 \\
Saskatchewan $(\mathrm{n}=13)$ & 114,082 & 3.88 & 3.33 & 314,100 \\
Manitoba $(\mathrm{n}=47)$ & 150,027 & 3.96 & 3.33 & 232,175 \\
Ontario $(\mathrm{n}=420)$ & 67,123 & 4.09 & 3.34 & 210,711 \\
Québec $(\mathrm{n}=515)$ & 47,141 & 4.16 & 3.38 & 197,951 \\
New Brunswick $(\mathrm{n}=28)$ & 62,581 & 4.08 & 3.31 & 207,231 \\
Newfoundland $(\mathrm{n}=6)$ & Not available & 3.97 & 3.16 & 179,798 \\
Nova-Scotia $(\mathrm{n}=29)$ & 49,932 & 4.09 & 3.28 & 157,865 \\
Prince Edward Island $(\mathrm{n}=27)$ & 68,732 & 4.10 & 3.27 & \\
\hline
\end{tabular}

Table A2. Number and proportion of herds with different milking system types in different regions of Canada

\begin{tabular}{|c|c|c|c|c|c|}
\hline \multirow[b]{2}{*}{ Milking system } & \multicolumn{4}{|c|}{ Region $^{1}$} & \multirow[b]{2}{*}{$P$-value } \\
\hline & $\begin{array}{l}\text { Ontario, } \\
\% \text { (no.) }\end{array}$ & $\begin{array}{l}\text { Québec, } \\
\text { \% (no.) }\end{array}$ & $\begin{array}{c}\text { Atlantic } \\
(\mathrm{NB}, \mathrm{NS}, \mathrm{NF}, \mathrm{PEI}), \% \text { (no.) }\end{array}$ & $\begin{array}{c}\text { Western } \\
(\mathrm{BC}, \mathrm{AB}, \mathrm{SK}, \mathrm{MB}), \% \text { (no.) }\end{array}$ & \\
\hline Pipeline (tie-stall) & $21(214)$ & $41(415)$ & $3(30)$ & $2(22)$ & $<0.0001$ \\
\hline Parlor & $13(135)$ & $4(43)$ & $5(51)$ & $11(111)$ & \\
\hline Total & $34(349)$ & $45(458)$ & $8(81)$ & $13(133)$ & \\
\hline
\end{tabular}

Table A3. Number and proportion of herds with different milking system types by herd size

\begin{tabular}{lcccc}
\hline & \multicolumn{4}{c}{ Herd size } \\
\cline { 2 - 4 } & $\begin{array}{c}\text { < cows, } \\
\text { Milking system }\end{array}$ & $\begin{array}{c}37-80 \text { cows, } \\
\% \text { (no.) }\end{array}$ & $\begin{array}{c}>80 \text { cows, } \\
\% \text { (no.) }\end{array}$ & P-value \\
\hline Pipeline (tie-stall) & $39(263)$ & $55(371)$ & $7(47)$ & $<0.0001$ \\
Parlor & $14(47)$ & $28(95)$ & $58(198)$ & \\
Total & $30(310)$ & $46(466)$ & $24(245)$ & \\
\hline
\end{tabular}

